JPPUMA: Jurnal Ilmu Pemerintahan dan Sosial Politik UMA

(Journal of Governance and Political Social UMA)

Available online http://ojs.uma.ac.id/index.php/jppuma

\title{
Peran Pemerintah Provinsi Sumatera Utara dalam Proses Penyelesaian Permasalahan Sengketa/Konflik Areal Lahan
}

\section{The role of North Sumatra Provincial Government in Settlement Process of Land Dispute / Conflict Problems}

\author{
Ngadimin $^{1) *}$, Heri Kusmanto2) \& Isnaini'1) \\ 1) Magister Administrasi Publik, Universitas Medan Area, Indonesia \\ 2)Fakultas Ilmu Sosial dan Ilmu Politik, Universitas Sumatera Utara, Indonesia
}

\begin{abstract}
Abstrak
Sesuai dengan kewenangan Pemerintah Provinsi Sumatera Utara di bidang pertanahan, maka perlu dilihat lebih lanjut bagaimana peran pemerintah dalam proses penyelesaian permasalahan konfliks pertanahan. Konflik pertanahan yang berlangsung lama dan belarut-larut adalah sengketa/konflik lahan eks HGU PTPN II. Metode deskriptif digunakan untuk mendiskripsikan secara sistematis, faktual dan akurat terhadap penyelesaian permasalahan konfliks pertanahan. Hasil penelitian menunjukkan bahwa Pemerintah Provinsi Sumatera Utara melaksanakan kewenangannya yang penyelesaiannya terganjal sampai saat ini. Salah satu isi diktum dari SK BPN Nomor 42,43,43/2002 dan No. 10/204 yang memuat kalimat: menyerahkan Pengaturan, Penguasaan, Pemilikan, Pemanfaatan dan Penggunaan Tanah tersebut kepada Gubernur Sumatera Utara. Untuk selanjutnya diproses sesuai ketentuan peraturan perundangan yang berlaku, setelah memperoleh ijin dari Menteri. Permasalahan menjadi rumit, karena ijin tersebut tidak terbit sampai sekarang. Upaya untuk mencari solusi masih terus dilakukan termasuk dengan pemerintah pusat yaitu kementerian Dalam Negeri maupun Kementerian BUMN. Berdasarkan fakta lapangan, banyak kelompok masyarakat baik penuntut maupun pemohon juga perusahaan swasta yang saat ini menguasai lahan eks HGU PTPN II. Maka Pemerintah Provinsi Sumatera Utara harus sesegera mungkin mengadakan pendataan ulang dan verifikasi/permohonan yang disampaikan oleh kelompok masyarakat penuntut/pemohon, sehingga dapat diperoleh kebenaran yang seobjektif mungkin untuk memperoleh hak atas redistribusi tanah-tanah eks HGU tersebut.
\end{abstract}

Kata Kunci: Peran Pemerintah, Konflik Pertanahan, Lahan

Abstract

In accordance with the authority of the Provincial Government of North Sumatra in the field of land, it is necessary to see further how the role of government in the process of solving the problems of land conflicts. Long-term and protracted land conflicts are disputes / land conflicts of former HGU PTPN II. Descriptive method is used to describe in a systematic, factual and accurate to solve the problems of land conflicts. The result of the research shows that the North Sumatera Provincial Government executes its authority whose settlement is hampered until now. One of the contents of the dictum of BPN Decree Number 42, 43, 43 / 2002 and No. 10/204 which contains the sentence: submit the Arrangement, Ownership, Ownership, Utilization and Use of Land to the Governor of North Sumatra. For further processing in accordance with the provisions of applicable laws and regulations, after obtaining permission from the Minister. The problem becomes complicated, because the permit is not published until now. Efforts to find solutions still continue to be done, including with the central government of the Ministry of Home Affairs and the Ministry of SOEs. Based on the facts of the field, many community groups, both claimants and applicants are also private companies that currently control the land of former HGU PTPN II. So the North Sumatera Provincial Government should immediately conduct a re-registration and verification / petition submitted by the claimant / appealing community group, so as to obtain the truth as objectively as possible to obtain the right to redistribution of the former land of HGU.

Keywords: Role of Government, Land Conflict, Land

How to Cite: Ngadimin. Kusmanto, H. \& Isnaini. (2018). Peran Pemerintah Provinsi Sumatera Utara dalam Proses Penyelesaian Permasalahan Sengketa/Konflik Areal Lahan. JPPUMA: Jurnal Ilmu Pemerintahan dan Sosial Politik UMA, 6 (1): 25-37.

*Corresponding author: ISSN 2549-1660 (Print)

E-mail: hambalingadimin01@gmail.com ISSN 2550-1305 (Online) 
Ngadimin, Heri Kusmanto \& Isnaini, Peran Pemerintah Provinsi Sumatera Utara dalam

\section{PENDAHULUAN}

Menurut Winataputra (2007) kesadaran berkonsti Tanah adalah karunia dari Tuhan Yang Maha Esa kepada umat manusia di muka bumi. Tanah menjadi kebutuhan dasar manusia. Sejak lahir sampai meninggal dunia, manusia membutuhkan tanah untuk tempat tinggal dan sumber kehidupan. Secara kosmologis, tanah adalah tempat manusia tinggal, tempat bekerja dan hidup, tempat dari mana mereka berasal dan akan kemana pula mereka pergi. Dalam hal ini tanah mempunyai dimensi ekonomi, sosial, kultural politik dan ekologis.

Dalam sejarah peradaban umat manusia, tanah merupakan faktor yang paling utama dalam menentukan produksi setiap fase peradaban. Tanah tidak hanya mempunyai nilai ekonomis tinggi, tetapi juga nilai filosofis, politik, sosial, dan kultural. Tidak mengherankan jika tanah menjadi harta istimewa yang tidak henti-hentinya memicu berbagai masalah sosial yang kompleks dan rumit.

Menyadari nilai dan arti penting tanah, para pendiri Negara Kesatuan Republik Indonesia (NKRI) merumuskan tentang tanah dan sumber daya alam secara ringkas tetapi sangat filosofis substansial di dalam Konstitusi, Pasal 33 Ayat (3) Undang-undang Dasar 1945, yaitu"Bumi dan air dan kekayaan alam yang terkandung di dalamnya dikuasai oleh Negara dan dipergunakan untuk sebesar-besar kemakmuran rakyat".

Sebagai sumber agraria yang paling penting, tanah merupakan sumber produksi yang sangat dibutuhkan sehingga ada banyak kepentingan yang membutuhkannya. Perkembangan penduduk dan kebutuhan yang menyertainya semakin tidak sebanding dengan luasan tanah yang tidak pernah bertambah. Karena itulah, tanah dan segala sumber daya alam yang terkandung di dalamnya selalu menjadi "ajang perebutan" berbagai kepentingan yang senantiasa menyertai kehidupan manusia. Tidak heran jika sejak zaman dahulu tanah selalu menjadi obyek yang diperebutkan sehingga memunculkan adanya sengketa dan konflik yang berkaitan dengan tanah dan sumber daya yang dikandungnya. Disamping itu Adanya ketimpangan struktur penguasaan, pemilikan, penggunaan, dan pemanfaatan tanah serta ketimpangan terhadap sumber-sumber produksi lainnya menyebabkan terjadinya konflik pertanahan.

Konflik pertanahan merupakan persoalan yang kronis dan bersifat klasik serta berlangsung dalam kurun waktu tahunan bahkan puluhan tahun dan selalu ada dimanamana. Sengketa dan konflik pertanahan adalah bentuk permasalahan yang sifatnya kompleks dan multi dimensi. Oleh karena itu usaha pencegahan, penanganan dan penyelesaiannya harus memperhitungkan berbagai aspek baik hukum maupun non hukum. Seringkali penanganan dan penyelesaian terhadap sengketa dan konflik pertanahan dihadapkan pada dilema-dilema antara berbagai kepentingan yang sama-sama penting. Mencari keseimbangan atau win-win solution atas konflik yang sudah terjadi jelas membutuhkan 
upaya yang tidak mudah. Karena itu dibutuhkan pemahaman mengenai akar konflik, faktor pendukung dan faktor pencetusnya sehingga dapat dirumuskan strategi dan solusinya. Dengan usaha-usaha penyelesaian akar masalah, diharapkan sengketa dan konflik pertanahan dapat ditekan semaksimal mungkin, sekaligus menciptakan suasana kondusif dan terwujudnya kepastian hukum dan keadilan agraria yang mensejahterakan.

Dalam konteks provinsi Sumatera Utara, konflik pertanahan yang telah terjadi begitu lama dan melibatkan banyak sekali elemen masyarakat serta melibatkan areal lahan yang begitu luas adalah sengketa/konflik lahan eks HGU PTPN II.

Sengketa/konflik lahan eks HGU PTPN II dimulai pada tahun 2002 melalui SK BPN Pusat No, 42, 43, dan 44 /HGU/ BPN/2002 dan SK nomor 10/2004 tentang Pemberian Perpanjangan Jangka Waktu Hak Guna Usaha. Pemerintah pusat melalui Badan Pertanahan Nasional (BPN) mengeluarkan tanah seluas 5.873,068 ha dari HGU PTPN II. Dari 5.873,068

ha itu sebanyak $3.366,55$ ha terletak di kabupaten Deli Serdang, 1.210,868 ha di Kabupaten Langkat dan 238,52 ha di kota Binjai. Sementara sebanyak 1.057,13 ha lagi masih menunggu putusan kepala BPN pusat. Menurut Gubernur Sumatera Utara (2003) yang ketika itu masih dijabat oleh Alm. Tengku. Rizal Nurdin, dari 5.873,068 ha itu seluas 2.641,47 ha diperuntukan untuk Rencana Umum Tata Ruang Wilayah Kabupten dan Kota (RUTRWK). Sementara sisanya, untuk memenuhi tuntutan rakyat yang memiliki alas hak yang sah, untuk tuntutan rakyat, garapan rakyat, untuk masyarakat adat, serta untuk perumahan pensiunan karyawan perkebunan.

Dikeluarkanya tanah seluas 5.873,068 ha dari HGU PTPN II pada kenyataanya bukan menjadi tonggak baru bagi penyelesaian konflik agraria di Sumatera Utara terutama yang berkaitan dengan PTPN II, justru sebaliknya menjadi awal dari perluasan konflik yang tak kunjung selesai hingga sekarang.

Tabel 1.1

Rencana Peruntukkan dan Penggunaan Areal

\begin{tabular}{|l|l|l|l|l|}
\hline $\begin{array}{l}\text { Rencana peruntukan penggunaan } \\
\text { tanah }\end{array}$ & $\begin{array}{l}\text { Kab. Deli } \\
\text { serdang }\end{array}$ & Kab. Langkat & Kota binjai & Jumlah \\
\hline Tuntutan Rakyat & $909,72 \mathrm{Ha}$ & $467,40 \mathrm{Ha}$ & - & $1.377,12 \mathrm{Ha}$ \\
\hline Garapan Rakyat & $302,26 \mathrm{Ha}$ & $120,26 \mathrm{Ha}$ & $122,90 \mathrm{Ha}$ & $546,12 \mathrm{Ha}$ \\
\hline RUTRW non Pertanian & $2.219,70 \mathrm{Ha}$ & $308,47 \mathrm{Ha}$ & $133,30 \mathrm{Ha}$ & $2.641,47 \mathrm{Ha}$ \\
\hline Perumahan Pensiunan Karyawan & $441,99 \mathrm{Ha}$ & $114,04 \mathrm{Ha}$ & $2,32 \mathrm{Ha}$ & $558,35 \mathrm{Ha}$ \\
\hline Masyarakat Melayu & $200,00 \mathrm{Ha}$ & $200,00 \mathrm{Ha}$ & $50,00 \mathrm{Ha}$ & $450,00 \mathrm{Ha}$ \\
\hline Pengembangan USU & $300,00 \mathrm{Ha}$ & - & - & $300,00 \mathrm{Ha}$ \\
\hline JUMLAH
\end{tabular}

Sumber: Biro Pemerintahan Setda Provsu, 2015

Dengan keluarnya kebijakan pelepasan ternyata memunculkan masalah, sebab lahan yang tidak diperpanjang HGU nya pengeluaran tanah seluas 5.873,068 ha dari 
Ngadimin, Heri Kusmanto \& Isnaini, Peran Pemerintah Provinsi Sumatera Utara dalam

HGU PTPN II tersebut tidak dibarengi dengan peta posisi tanah, dalam SK BPN Pusat No, 42, 43, dan 44 / HGU/ BPN/2002. Pemerintah pusat hanya menyebutkan luasan tanah yang dikeluarkan dan jumlah lahan di masingmasing daerah tanpa menyebut lokasi (desa, kecamatan, apalagi potok-pokok tanah yang memudahkan identifikasi keberadaan tanah tersebut).

Mensikapi kondisi ini, maka Gubernur Sumateera Utara mengeluarkan keputusan dengan membentuk Tim B Plus sesuai SK Gubsu No 593.4/065/K/2000 tanggal 11 Februari 2000 Jo No 593.4/2060/K/2000 tentang penyelesaian Masalah/ Tuntutan/ Garapan rakyat di lahan PTPN II. Tim B Plus ini terdiri dari Pemerintah Provinsi Sumut, Pemkab Deliserdang, Langkat, Kota Binjai dan BPN Sumut. Tim ini tidak melibatkan pihak PTPN 2 dan masyarakat karena tim B plus ini merupakan tim yang diberi tugas untuk melakukan pemeriksaan terhadap lahan yang dituntut oleh rakyat dan lahan yang diajukan perpanjangan HGU oleh PTPN2. Hasil dari pekerjaan dari Tim ini adalah matriks lahan eks HGU PTPN II yang sudah dibagi berdasarkan luasan lahan, lokasi tanah dan siapa yang berhak terhadap lahan tersebut.

Eksekusi pendistribusian lahan eks HGU PTPN II ini ternyata tidak seperti perencanaan di awal, sebab Pemerintah Provinsi Sumatera Utara terganjal oleh regulasi. Dalam SK BPN No.42, 43 dan 44/HGU/BPN/2002 dan 10/2004, telah disebutkan bahwa tanah-tanah perkebunan yang tidak di perpanjang tersebut akan menjadi tanah yang dikuasai langsung oleh negara dan menyerahkan pengaturan/penguasaan, pemilikan, pemamfaatan dan penggunaan tanah tersebut kepada Gubernur Propinsi Sumatra Utara dan selanjutnya di proses sesuai ketentuan dan perundang-undangan yang berlaku setelah memperoleh ijin pelepasan aset dari Menteri yang berwenang dalam hal ini Menteri BUMN RI. Selanjutnya naskah ijin pelepasan dari kementerian yang berwenang tidak kunjung keluar.

Guna menindaklanjuti maksud Surat Keputusan Kepala Badan Pertanahan Nasional No. 42,43,44/HGU/BPN/2002 dan SK No.10/HGU/BPN/2004 pada point ke 4 (empat) yaitu, memperoleh ijin pelepasan asset dari Menteri yang berwenang, Gubernur Sumatera Utara telah 7 (tujuh) kali memohon ijin pelepasan asset kepada Menteri Negara BUMN RI namun sampai saat ini belum mendapatkannya juga, yaitu melalui surat: No. 593/0763/2003 tanggal 30 Januari 2003; No. 593/2582/2003 tangal 16 April 2003; No. 593/6163/2003 tanggal 25 Juli 2003; No. 593/6969/2004 tanggal 29 November 2004; No. 593/11900/2010 tanggal 24 Nov 2010; No. 593/968/2013/ tanggal 11 Februari 2013; No. 593/13598 tanggal 26 Nopember 2014.

Situasi ini memberikan peluang dan ruang pada spekulan (untuk tidak menyebut mafia) tanah untuk turut andil dalam perebutan tanah eks HGU PTPN tersebut, bahkan dibeberapa daerah semisal Kabupaten Deli Serdang tanah-tanah yang diduga eks HGU PTPN II tersebut telah berubah menjadi hak milik pegusaha tertentu yang kemudian 
menyulap tanah-tanah tersebut menjadi perumahan mewah, perkebunan, pusat pertokohan dan lain sebagianya. Selain itu, pihak Perkebunan Nusantara (direksi) secara ekonomi juga memiliki kepetingan terhadap tanah-tanah tersebut. Contoh kasus yang paling banyak terjadi adalah sewa menyewa lahan perkebunan yang diduga eks HGU oleh oknum PTPN II kepada beberapa pengusaha, baik untuk penenaman tebu, jagung dan lain sebagainya.

Berkenaan dengan proses penyelesaian permasalahan areal lahan eks |HGU PTPN II masih banyak pertanyaan yang harus dijawab seperti, Siapa yang akan menjadi subyek (penerima manfaat langsung pembagian tanah), dengan cara bagaimana redistribusi tanah ini akan dilakukan dan apa bentuk hak yang akan timbul atas tanah-tanah tersebut, program ikutan apa yang akan dijalankan oleh pemerintah untuk melindungi para penerima manfaat program serta bagaimana status tanah yang sudah berpindah kepada pihak lain baik sebagai hak milik maupun sewa. Selain itu, berdasarkan peraturan dan perundangundangan yang ada pengaturan dan penetapan hak atas tanah tidak berada di dalam wilayah kewenangan Gubernur. Maka masyarakat yang selama ini melakukan reclaiming dan sebagian telah melakukan pengeloaan terhadap tanah tersebut akan menjadi pihak yang dirugikan sebab kebanyakan dari mereka tidak memiliki alas hak sebagaimana yang diatur dalam KUHP Perdata (kecuali alas historis).
Kondisi ini telah menjadi polemik baru pada situasi konflik agraria di Sumatera Utara. Sebab jika redistribusi salah sasaran, bukan penyelesaian yang akan terjadi tetapi justru konflik baru. Kedua, Sebagaimana yang dijelaskan oleh AP Parlindungan (Komentar Atas UU Pokok Agraria. (42-44.2008), bahwa wewenang hak menguasai dari Negara dalam:

a. Mengatur dan menyelenggarakan peruntukkan, penggunaan, persediaan dan pemeliharaannya.

b. Menentukan dan mengatur hak-hak yang dapat dipunyai atas (bagian dari) bumi, air dan ruang angkasa.

c. Menentukan dan mengatur hubunganhubungan hukum antara orang-orang dan perbuatan hukum mengenai bumi, air dan ruang angkasa.

Penjelasan baik yang diungkapkan oleh AP Parlindungan, ini paling tidak menyapaikan dua pesan. Pertama bahwa domain redistribusi tanah bukanlah kewenangan Pemerintah Daerah tetapi adalah kewenangan Pemerintah Pusat cq Badan Pertanahan Nasional. Ada nomenklatur yang berbeda antara saat pengusulan pelepasan HGU PTPN II seluas 5.873,068 ha pada tahun 2002 - 2003 dengan realitas sekarang ini (2017). Harus diingat bahwa pada saat usulan pelepasan tersebut Indonesia masih memakai undangundang No 22 tahun 2002 yang memberikan ruang yang cukup luas pada pemerintah daerah khususnya pemerintah kabupaten/kota mengenai soal-soal pertanahan termasuk penetapan subjek dan objek redistribusi tanah. Yang saat ini telah 
direduksi dengan keluarnya undang-undang no 23/2014 serta peraturan-peraturan lainnya yang mengarah pada resentralisasi bidang pertanahan.

Realitas ini menyampaikan Pesan Kedua bahwa sekalipun menurut SK BPN No.42, 43 dan 44/HGU/BPN/2002 dan 10/2004, telah disebutkan bahwa tanah-tanah perkebunan yang tidak di perpanjang tersebut akan menjadi tanah yang dikuasai langsung oleh negara dan menyerahkan pengaturan/penguasaan, pemilikan, pemampaatan dan penggunaan tanah tersebut kepada Gubernur Provinsi Sumatra Utara dan selanjutnya di proses sesuai ketentuan dan perundang-undangan yang berlaku setelah memperoleh ijin pelepasan aset dari Menteri yang berwenang dalam hal ini Menteri BUMN RI. Namun berdasarkan peraturan dan perundang-undangan yang ada pengaturan dan penetapan hak atas tanah tidak berada didalam wilayah kewenangan Gubernur.

Sebagai pejabat dekonsentrasi, Gubernur bisa saja melakukan langka-langkah koordinatif seperti yang dilakukan sekarang (Forum Pimpinan Daerah : kejaksaan, Kepolisian, Pengadilan, BPN, dan pemerintah kabupaten kota terkait), namun jika mekanisme redistribusi termasuk bentuk hak ditimbulkan atas reditribusi, serta penyelesaian (pengambilalihan kembali lahan yang sudah bersertifikat atas nama pengusaha), tidak di buat dengan benar, efektif, dan transparan maka sangat terbuka peluang rencana yang ada akan dijalankan berakhir dengan kegagalan.
Berdasarkan uraian di atas, maka perlu diteliti lebih jauh langkah-langkah yang sudah dilakukan oleh Pemerintah Provinsi Sumatera Utara dalam rangka mempersiapkan kebijakan strategis guna mengantisipasi kemungkinan kedepan. Jika langkah-langkah yang telah diambil masih menemui jalan buntu, maka melalui analisis peran yang dilaksanakan akan dapat dievaluasi kelemahan kebijakan guna terus mendorong issue lahan eks HGU PTPN II ke pemerintah pusat, agar pemerintah pusat melakukan langkah-langkah penyelesaian kasus ini yang telah mengambang selama puluhan tahun.

\section{METODE PENELITIAN}

Metode Penelitian yang digunakan dalam penelitian ini adalah metode deskriptif dengan maksud hassil penelitian akan memberikan gambaran atau mendeskripsikan secara sistematis, factual dan akurat terhadap obyek yang akan diteliti.

Dengan demikian, metode deskriptif yang dimaksudkan dalam penelitian ini adalah metode deskriptif dengan maksud hasil penelitian akan memberikan gambaran atau mendeskripsikan fakta-fakta yang ditemui di lapangan yang berhubungan dengan peran Pemerintah Provinsi Sumatera Utara dalam proses penyelesaian sengketa/konflik areal eks HGU PTPN II.

\section{HASIL DAN PEMBAHASAN}

Berdasarkan uraian-uraian kronologis di atas, untuk menyikapi terbitnya Surat Meneg BUMN Nomor. S.567/MBU/09/2014 tanggal 
30 September 2014 perihal penyelesaian permasalahan areal Eks. HGU PTPN II dan Surat Meneg BUMN Nomor: 530/MBU/01/2015 tanggal 14 Januari 2015 perihal Penyelesaian Permasalahan areal Eks. HGU PTPN II yang merupakan surat jawaban Meneg. BUMN RI atas Surat Gubernur Sumatera Utara Nomor: 593/13598 tanggal 26 November 2014 perihal penyelesaian permasalahan areal eks HGU PTPN II yang menurut hemat kami surat terakhir Meneg BUMN RI merupakan penegasan dari surat sebelumnya dan meminta Gubernur Sumatera Utara untuk memastikan daftar nominatif penerima lahan kepada yang berhak.

Berkenaan dengan hal tersebut beberapa saran pendapat kepada Bapak adalah sebagai berikut: Surat Meneg BUMN RI Nomor: 5567/MBU/09/2014 tanggal 30 September 2014 menyangkut Penyelesaian Permasalahan Areal Lahan HGU diperpanjang seluas 56.341,85 Ha dan lahan HGU yang tidak diperpanjang seluas 5.873, 06 Ha yang berlandaskan pada Pendapat Hukum (Legal Opinion) JAMDATUN Kejagung RI, pada intinya memutuskan sebagai berikut: 1) Penerbitan sertifikat untuk HGU yang diperpanjang dan usulan penerbitan HGU baru untuk lahan yang dipertahankan (Dari HGU yang tidak diperpanjang); 3) Pemindahtanganan dengan penjualan atau ganti rugi, penjualan dengan penawaran umum,/penawaran terbatas/ penunjukan langsung (dalam hal ini memenuhi persyaratan kondisi tertentu); 3) Penghapusbukuan secara administrasi untuk lahan yang telah didivestasi sebelumnya.

Surat Meneg BUMN RI Nomor: 5567/MBU/09/2014 tanggal 30 September 2014 apabila dianalisis berdasarkan Peraturan Perundang-Undangan di bidang pertanahan sangat tidak mendasar bahkan bertentangan, hal ini dapat digambarkan sebagai berikut: 1) Penerbitan sertifikat untuk HGU yang diperpanjang dan usulan penerbitan HGU baru untuk lahan yang dipertahankan (dari HGU yang tidak diperpanjang). Keputusan Mentri BUMN ini sangat bertentangan dan tidak mematuhi kewenangan BPN yang diberikan oleh Negara berdasarkan peraturan perundang-undangan di bidang pertanahan untuk mengatur dan pemberian hak atas tanah serta kewajiban-kewajiban yang harus dipatuhi oleh pemegang hak atas tanah (Undang-Undang Nomor 5 Tahun 1960, Peraturan Pemerintah Nomor 40 Tahun 1996, Peraturan Pemerintah Nomor 24 Tahun 1997, Peraturan Pemerintah Nomor 46 Tahun 2002, Keputusan Presiden Nomor 10 Tahun 2001, Keputusan Presiden Nomor 103 Jo. Nomor 3 Tahun 2002, Keputusan Presiden Nomor 110 Tahun 2001 Jo. Nomor 5 Tahun 2002, Keputusan Presiden Nomor 309 Tahun 2001, Peraturan Menteri Negara Agraria/Kepala BPN Nomor 3 Tahun 1997, Peraturan Menteri Agraria/Kepala BPN Nomor 3 Tahun 1999, Peraturan Menteri Agraria/Kepala BPN Nomor 9 Tahun 1999, Keputusan Kepala BPN Nomor 6 Tahun 2001, Keputusan Kepala BPN Nomor 12 Tahun 2001)(fotocopy terlampir), terhadap perpanjangan dan tidak diperpanjangnya HGU PT Perkebunan Nusantara II (Persero) telah 
Ngadimin, Heri Kusmanto \& Isnaini, Peran Pemerintah Provinsi Sumatera Utara dalam

diputus berdasarkan surat Keputusan Kepala Badan Pertanahan Nasional antara lain:

1. Keputusan Kepala Badan Pertanahan Nasional Nomor: 42/HGU/BPN/2002 tentang Pemberian Perpanjangan jangka waktu Hak Guna Usaha atas Tanah terletak di Kabupaten Deli Serdang Propinsi Sumatera Utara dengan luas HGU yang diperpanjang yakni 14.503.1100 Ha dan HGU yang tidak diperpanjang seluas 3.353.5900 Ha.

2. Keputusan Kepala Badan Pertanahan Nasional Nomor: 43/HGU/BPN/2002 tentang Pemberian Perpanjangan Jangka waktu Hak Guna Usaha atas Tanah terletak di Kabupaten Langkat Propinsi Sumatera Utara dengan luas HGU yang diperpanjang yakni 1.866,8600 Ha dan HGU yang tidak diperpanjang seluas 1.210,8680 Ha.

3. Keputusan Kepala Badan Pertanahan Nasional Nomor: 44/HGU/BPN/2002 tentang Pemberian Perpanjangan jangka waktu Hak Guna Usaha atas Tanah terletak di Kota Binjai Provinsi Sumatera Utara dengan yang amar putusannya menyatakan menolak permohonan perpanjangan jangka waktu HGU PT Perkebunan Nusantara II (Persero) seluas 238,52 Ha.

4. Keputusan Kepala Badan Pertanahan Nasional Nomor: 10/HGU/BPN/2004 tentang Pemberian Hak Guna Usaha Atas Tanah yang Terletak di Kabupaten Deli Serdang Provinsi Sumatera Utara Dengan Luas HGU Yang Diperpanjang Seluas
1.360.69, 00 Ha dan HGU Yang Tidak Diperpanjang Seluas 1.057.12,00 Ha.

Keputusan kepala BPN terkait HGU yang tidak diberikan perpanjangan dalam dictum putusannya menyatakan Menyerahkan pengaturan penguasaan, pemilikan, pemanfaatan dan penggunaan tanah tersebut kepada Gubernur Sumatera Utara untuk selanjutnya diproses sesuai ketentuan peraturan perundangan yang berlaku setelah memperoleh ijin pelepasan asset dari Menteri yang berwenang. Hal ini tentunya keputusan Menteri BUMN yang menyatakan bahwa usulan penerbitan HGU baru untuk lahan yang dipertahankan (dari HGU yang tidak diperpanjang) sangat bertentangan dengan keputusan Kepala BPN sehingga dapat dikatakan tidak mempunyai kekuatan hukum mengikat dan menyalahi aturan administrasi pertanahan.

Perlu juga ditambahkan berdasarkan Pasal 34 Undang - Undang Pokok Agraria dan Pasal 17 Peraturan Pemerintah Nomor 40 Tahun 1996 antara lain dinyatakan bahwa salah satu penyebab hapusnya HGU adalah karena berakhirnya jangka waktu sebagaimana ditetapkan dalam keputusan pemberian atau perpanjangannya. Hapusnya HGU tersebut menurut Pasal 17 ayat (2) Peraturan Pemerintah Nomor 40 Tahun 1996 mengakibatkan tanahnya menjadi tanah yang dikuasai langsung oleh Negara. Selanjutnya Pasal 12 ayat 1 hurug g dan $\mathrm{h}$ Peraturan Pemerintah Nomor 40 Tahun 1996 menyatakan bahwa bekas pemegang hak wajib menyerahkan kembali tanah yang diberikan 
dengan HGU kepada Negara sesudah HGU hapus dan menyerahkan sertifikat HGU yang telah hapus kepada Kantor Pertanahan. Terkait Gubernur Sumatera Utara telah menyurati BPN RI untuk merubah dictum putusan kepala BPN RI namun tidak pernah ditanggapi sampai saat ini.

Keputusan Menteri BUMN yang menyatakan "Pemindahtanganan dengan penjualan atau ganti rugi. Penjualan dengan penawaran umum/penawaran terbatas/penunjukan langsung (dalam hal memenuhi persyaratan kondisi tertentu) terhadap tanah yang HGU telah diperpanjang maupun HGU nya yang tidak diperpanjang adalah sangat tidak mendasar dan bertentangan dengan peraturan perundangundangan serta tidak patuh pada Surat Keputusan Kepala BPN khususnya terhadap HGU yang tidak diperpanjang. Terhadap HGU yang diperpanjang berdasarkan Peraturan Perundang-Undangan PT Perkebunan Nusantara II (Persero) tidak berhak untuk melakukan tindakan Pemindahtanganan dengan penjualan atau ganti rugi. Penjualan dengan penawaran umum/ penawaran terbatas/ penunjukan langsung karena PT Perkebunan Nusantara II (Persero) adalah penerima dan pemegang hak atas tanah berupa HGU bukan pemilik tanah (dalam konsep hak menguasai oleh Negara) sehingga tidak memiliki kewenangan untuk mengalihkan tanah yang tidak sesuai dengan peruntukannya. Sesuai dengan aturan hukum di bidang pertanahan bahwa HGU yang tidak digunakan sesuai dengan peruntukannya maka
HGU dimaksud dapat hapus sehingga konsekuensinya berdasarkan Pasal 17 ayat (2) Peraturan Pemerintah Nomor 40 Tahun 1996 terhadap hapusnya HGU mengakibatkan tanahnya menjadi tanah yang dikuasai langsung oleh Negara. Hal ini juga termasuk divestasi yang dilakukan PT Perkebunan Nusantara II (Persero) kepada pihak ketiga sangat bertentangan dengan peraturan perundang-undangan dan tidak dibenarkan bagi pemegang hak atas tanah berupa HGU ditambah lagi dengan keputusan Menteri BUMN untuk dihapusbukukan secara administrasi dan dipecah dari sertifikat induk terhadap tanah HGU yang telah dikuasai oleh pihak ketiga yang tidak berorientasi pada kepentingan umum, namun dengan tujuan komersil.

Terhadap surat Meneg BUMN Nomor: 530/MBU/01/2015 tanggal 14 Januari 2015 perihal Penyelesaian Permasalahan Areal Eks.HGU PTPN II yang intinya mohon dukungan dari Gubernur Sumatera utara untuk memastikan daftar Nominatif penerima lahan tersebut yang akan ditetapkan nantinya sebagai pihak yang berhak, berkenaan dengan hal tersebut dapat kami sarankan sebagai berikut: 1) Agar Pemerintah Provinsi Sumatera Utara membentuk Tim Kajian dan Analisis Hukum yang melibatkan Instansi Teknis dan Fakar Hukum Peratanahan (Akademisi) untuk menelaah keputusan dan kebijakan serta landasan hukum yang telah diambil Tim B Plus dan pihak PTPN II maupun Meneg BUMN RI terkait objek tanah lahan Eks. HGU maupun lahan HGU PTPN II 
(sebagaimana yang telah kami uraikan pada point sebelumnya); 2) Konsultasi Hasil Kajian Hukum (Point 1) kepada Pemerintah Pusat (Meneg BUMN RI, BPN RI, Mendagri) guna mendapatkan Payung Hukum dan menyepakati Format/Metode serta Bimbingan Supervisi untuk Penyelesaian dan keikutsertaan Pemerintah Pusat dalam menyelesaiakan/pengawasan atas permasalahan Eks. HGU PTPN II; 3) Membentuk Tim Khusus (Task Force) untuk Penyelesaian permasalahan Eks. HGU PTPN II yang melibatkan Forum Komunikasi Pimpinan Daerah (FKPD ) dan instansi terkait baik pusat ( Meneg BUMN RI , BPN RI,Mendagri) maupun daerah, karena dikhawatirkan dalam penyelesaian permasalahan tanah ini apabila tidak cermat dan bijak, diperkirakan akan dapat menimbulkan konflik baik vertikal maupun horizontal ditengah-tengah masyarakat.

Menentukan Skala Prioritas

Penyelesaian dari Rencana Peruntukan dan Penggunaan Eks. HGU PTPN II seluas 5.873,06 Ha (Sesuai dengan SK BPN Nomor:42,43,44 /HGU/BPN/2002 tanggal 29 November 2002 dan Nomor 10 /HGU/BPN/ 2004 tanggal 6 Februari 2004) dengan tetap mengacu kepada hasil keputusan-keputusan Tim B Plus,dan mengedepankan Aspek Hukum, Politik, Sosial Ekonomi Masyarakat, dan Keadilan dalam Penyelesaian Rencanan Peruntukan dan Penggunaan Lahan EKS HGU PTPN II seluas 5.873.06 Ha yang terletak di Kabupaten Deli Serdang, Kabupaten Langkat dan Kota Binjai, antara lain Tuntutan (1.377,12 Ha), Garapan
$(546,12)$, Perumahan Karyawan $(558,35 \mathrm{Ha})$, RUTRWK (2.641,47 Ha), Penghargaan Masyarakat (450.000 Ha).

Setelah mempelajari dari Peraturanperaturan yang menyangkut Bidang Pertanahan dan kebijakan yang telah dikeluarkan / dilaksanakan baik oleh Tim B Plus sebelumnya dan kebijakan oleh PTPN II maupun dari Instansi Pusat (Meneg BUMN RI dan BPN RI) serta mencermati perkembangan situasi dan kondisi di lapangan yang telah berlangsung \pm 15 tahun khususnya di areal Eks HGU PTPN II, merupakan salah satu penyumbang tertinggi dalam eskalasi konflik bidang pertanahan di Provinsi Sumatera Utara, berkenaan dengan hal tersebut disarankan kepada Bapak agar Pemerintah Provinsi Sumatera Utara secara aktif untuk komunikasi dan konsultasi yang melibatkan Instansi Pusat (Meneg BUMN RI, BPN RI, Menkumhan RI, Mendagri, Kejagung RI) guna mendapat Payung Hukum, Format/Metode dan Bimbingan Supervisi yang akan digunakan dalam menyelesaikan masalah Eks HGU PTPN II nantinya, mengingat kondisi di lapangan saat ini disinyalir telah terjadi jual beli lahan tanah negara dan terbitnya sertifikat Hak Milik di lokasi lahan Eks. HGU dimaksud, disamping itu surat - surat dan Keputusan Meneg BUMN RI serta payung hukum yang digunakan yang terkait Eks. HGU PTPN II tidak sinkron bahkan menurut hemat kami bertentangan dengan peraturan di bidang pertanahan, untuk itu Pemerintah Provinsi Sumatera Utara dalam Penangannya dan Kebijakannya harus benarbenar mencermati, menyikapi secara arif dan 
bijaksana dengan tetap mengedepankan Aspek Hukum, Politik, Sosial Ekonomi, Sosial Budaya (Heterogenitas) dan Keadilan dalam penyelesaian (Regulasi).

Adapun Skema Penyelesaian yang dapat menjadi bahan diskusi (kajian dasar) baik kepada Instansi Teknis maupun Fakar Hukum (Akademisi) sebelum ditawarkan kepada Pemerintah Pusat guna mendapatkan Payung Hukum Format/Metode penyelesaian serta Bimbingan Supervisi, adalah sebagai berikut: 1) Tanggapan Atas Surat Tanggapan Atas Surat Menteri Badan Usaha Milik Negara Republik Indonesia Nomor: S - 567/ MBU/09/ 2014 tanggal 30 September 2014 dan Surat Menteri Badan Usaha Milik Negara Republik Indonesia Nomor: S - 30/MBU/01/2015 tentang Penyelesaian Permasalahan Areal Lahan HGU Diperpanjang Seluas 56.341,85 Ha dan Lahan HGU Yang Tidak Diperpanjang Seluas 5.873,06 Ha Serta Aset Berupa Bangunan Rumah Dinas Milik PT. Perkebunan Nusantara II (Persero). Ditujukan Kepada Direksi PT. Perkebunan Nusantara II (Persero) Tanjung Morawa Medan.

Dari total HGU yang tidak diperpanjang seluas 5.873, 06 Ha terdiri dari: Area yang dapat dipertahankan seluas 1.633,37 Ha. Meneg BUMN merekomendasikan Usulan Penerbitan HGU baru.

Tanggapannya: Apakah HGU yang tidak diperpanjang oleh PTPN II yang sudah lebih dari 15 tahun fisik tanah telah dikuasai oleh PTPN II walaupun Hak Atas Tanah belum diperoleh dapat dibenarkan menurut Peraturan Perundang - Undangan. Apakah
Peraturan Perundang - Undangan yang mengatur tentang Pendaftaran Tanah, Penerbitan Hak Atas Tanah dan Perpanjangan Hak yang diberikan oleh Negara tidak berlaku bagi PTPN II.

Area Lahan yang dilepas termasuk yang sudah didivestasi dan dipinjampakai seluas 3.995,94 Ha. Meneg BUMN merekomendasikan untuk Pemindahtanganan dan Penghapusbukuan.

Tanggapannya, Apakah PTPN II masih memiliki kewenangan atas HGU yang tidak diperpanjang (lihat Konsep Hak Menguasai oleh Negara di dalam UUPA). Apakah pemindahtanganan yang akan dilakukan oleh PTPN II tidak bertentangan dengan Peraturan Perundang-undangan yang memberikan kewenangan kepada Pemerintah Daerah. Apakah Pemindahtanganan sebagaimana direkomendasikan Meneg BUMN kepada PTPN II terhadap area HGU yang tidak diperpanjang tidak menimbulkan konflik.

\section{SIMPULAN}

Konflik agraria di Indonesia dan Sumatera Utara Khususnya sepertinya telah menjadi persoalan tanpa ujung. Yang terjadi bukan hanya tidak dapat diselesaikannya kasus-kasus lama, namun eskalasi konflikkonflik baru juga mengalami peningkatan sampai pada titik yang cukup mengkhawatirkan. Rasio jumlah tanah untuk pertanian dengan jumlah kebutuhan penduduk terhadap tanah yang timpang, serta tidak ditempatkanya investasi pengelolaan sumber daya alam pada areal yang bijak, disinyalir 
menyadi penyebab utama mengapa konflik agraria di Indonesia menjadi semakin kompleks. Undang-undang pokok agraria No 5 tahun 1960 sebenarnya telah meletakkan tonggak dasar bagi penyelesaian persoalan tersebut. Namun berbagai peraturan perundang-undangan yang dilahirkan setelahnya, secara langsung ataupun tidak langsung telah membekukan undang-undang tersebut (UU PA). Fakta ini memberikan penjelasan pada kita bahwa persoalan konflik agraria tidaklah berdemensi tunggal apalagi keadaerahan. Ia (konflik agraria) tidaklah berada pada ruang hampa minus intervensi (internasional, nasional, maupun regional). Artinya penyelesaian konflik agraria terutama di Sumatera Utara, tidak bisa hanya didukung oleh niat baik pemerintah daerah, tapi harus mendapat dukungan pada skala yang lebih luas: pemerintah pusat, dan masyarakat sipil. Penyelesaian kasusu-kasus di daerah, dalam banyak kasus teryata disebabkan lambannya pemerintah pusat merepon permasalahan sehingga tidak jarang membuat pemerintahan di daerah tidak berani mengambil kebijakan, terutama kasus lahan eks HGU PTPN II ini, salah satunya adalah lambanya regulasi dari pemmerintah pusat, khususnya Kemeneg BUMN untuk melaakukan langkah-langkah strategis guna menyelesaikan hal ini. Pembiaran di lapangan terjadi selama puluhan tahun tanpa ada upaya atau skema penyelesaian secara komprehensif. Sepertinya carut marut dilapangan terus terjadi tanpa ada kehadiran negara di alamnya. Pemerintah pusat harus segera melakkukan langkah proaktif mengeluarkan regulasi yang berkaitan dengan mandegnya proses pelepasan izin HGU kepada pemerintah Provinsi Sumatera Utara dan Pemerintah daerah juga harus seggera bersiap menyiapkan segala sesuatunya yang berkaitan dengan Redistribusi lahan kepada masyarakat nantinya.

\section{DAFTAR PUSTAKA}

Harsono, B. (2003). Hukum Agraria Indonesia, Sejarah Pembentukan Undang-undang Pokok Agraria, Isi dan Pelaksanaannya, Penerbit Djambatan, Jakarta.

Hutagalung, A.S. \& Gunawan, M. (2009). Kewenangan Pemerintah di bidang Pertanahan, 2009, Penerbit Rajawali Pers, Jakarta.

Hutagalung, A.S. (2002). Serba Aneka masalah Tanah dalam Kegiatan Ekonomi Suatu Kumpulan Karangan, Penerbit Fakultas Hukum Universitas Indonesia, Jakarta.

Idham. (2004). Konsolidasi Tanah Perkotaan dalam Perfektif Otonomi Daearah, Penerbit Alumni, Bandung.

Marlina, dan Isnaini, (2011), Perspektif Hukum Perdata Dan Agrarian dalam Pengalihan Lahan Eks HGU PTPN II (Persero) Tanjung Morawa Kepada Pihak Ketiga, (Studi Pengalihan Lahan Eks Kepada Yayasan Al Washliyah dan Yayasan Nurul Amaliya), Mercatoria, 4 (2): 58-71

Sumardjono, M. (2006). Kebijakan Pertanahan antara Regulasi dan Implementasi, Kompas, Jakarta.

Indonesia, Undang-undang tentang Peraturan Dasar Pokok-pokok Agraria, UU No. 5 Tahun 1960 LN. 104 Tahun 1060, TLN No 2034

Indonesia, Undang-undang tentang Penataan Ruang, UU No. 26 Tahun 2007.

\section{Sumber lain :}

Surat Keputusan KBPN Nomor 42/HGU/BPN/2002 Tentang Pemberian Perpanjangan Pemberian Hak Guna Usaha atas Tanah terletak di Kabupaten Deli Serdang, Provinsi Sumatera Utara

Surat Keputusan KBPN Nomor 43/HGU/BPN/2002 Tentang Pemberian Perpanjangan Pemberian Hak Guna Usaha atas Tanah terletak di Kabupaten Langkat, Provinsi Sumatera Utara

Surat Keputusan KBPN Nomor 44/HGU/BPN/2002 Tentang Pemberian Perpanjangan Pemberian Hak Guna Usaha atas Tanah 
JPPUMA: Jurnal Ilmu Pemerintahan dan Sosial Politik UMA, 6 (1) (2018): 25-37

terletak di Kota Binjai, Provinsi Sumatera Utara

Surat Keputusan KBPN Nomor 10/HGU/BPN/2004, tanggal 6 Februari 2004, Tentang Pemberian Hak Guna Usaha atas Tanah terletak di Kabupaten Deli Serdang, Provinsi Sumatera Utara. 